\title{
Analisis Kesalahan Konsep Matematika Siswa dalam Menyelesaikan Soal Berdasarkan Taksonomi SOLO
}

\author{
Novita Ratnayanti ${ }^{*}$, Sumadji ${ }^{2}$, Vivi Suwanti ${ }^{3}$ \\ Pendidikan Matematika, Universitas PGRI Kanjuruhan, Malang, Indonesia ${ }^{\mathbf{1 , 2} 3}$ \\ novitaratnayanti503@gmail.com ${ }^{1}$, sumadji@unikama.ac.id ${ }^{2}$, \\ vivi_devbatghost@unikama.ac.id ${ }^{3}$
}

\begin{abstract}
Abstrak. Berdasarkan hasil observasi di SMPK St. Theresia Kaca siswa sering melakukan kesalahan dalam menyelesaikan soal pada materi sistem persamaan linear dua variabel. Penelitian ini bertujuan untuk menganalisis kesalahan konsep matematika siswa dalam menyelesaikan soal sistem persamaan linear dua variabel berdasarkan Taksonomi SOLO. Penelitian ini menggunakan pendekatan kualitatif dengan jenis penelitian deskriptif. Berdasarkan hasil penelitian, didapatkan bahwa jenis kesalahan pada indikator kemampuan menyatakan ulang sebuah konsep diantaranya menyatakan ulang sebuah konsep tidak lengkap dan tidak ada jawaban, jenis kesalahan pada indikator kemampuan memberikan contoh dan bukan contoh diantaranya memberikan contoh dan bukan contoh tidak lengkap, memberikan contoh dan bukan contoh tidak sesuai dan tidak ada jawaban dan jenis kesalahan pada indikator kemampuan mengaplikasikan konsep atau algoritma kepemecahan masalah diantaranya mengaplikasikan konsep atau algoritma kepemecahan masalah tidak lengkap dan tidak ada jawaban. Disimpulkan bahwa secara keseluruhan terdapat 21 dari 30 siswa yang melakukan kesalahan pada indikator pertama, pada indikator kedua secara keseluruhan terdapat 23 dari 30 siswa yang melakukan kesalahan, dan pada indikator ketigaasecara keseluruhan terdapat 14 dari 30 siswa yang melakukan kesalahan.
\end{abstract}

Kata Kunci: Kesalahan konsep, sistem persamaan linear dua variabel, taksonomi solo

\begin{abstract}
Based on the results of observations at SMPK St. Theresia Kaca students often make mistakes in solving problems on the material of the two-variable linear aquation system. The purpose of this study was to analyze the students' mathematical misconceptions in solving theetwo-variable linear aquation system problems based on the SOLO Taxonomy. This research uses a qualitative approach with descriptive research type. Based on the results of the research, it was found that the types of errors in the ablility to restate a concept include restating an incomplete concept and no answer, the types of errors in the ability to give examples and not not examples are not appropritate and there are no answer and types of
\end{abstract}


errors on the indicators of the ability to apply concepts or problem solving algorithms, including applying incomplete problem solving concepts or algortithms and no answer. It was concluding that overall there were 21 out of 30 students who made mistakes on the first indicator, on the second indicator overall there were 23 out of 30 students who made mistakes, and in the third indicator overall there were 14 out of 30 students who made mistakes.

Keywords: Misconceptions, two-variable system of linear equations, solo taxonomy

\section{Pendahuluan}

Matematika merupakan pelajaran yang membutuhkan konsentrasi untuk mengingat dan mendalami kembali materi yang dipelajari sehingga siswa harus mampu menguasai konsep materi tersebut. Dalam Permendiknas RI No. 22 tahun 2006, salah satu tujuan pembelajaran matematika pada pendidikan menengah adalah supaya siswa memahami konsep matematika, menjelaskan keterlibatan antar konsep dan mengaplikasikan konsep atau agoritma secara luwes, akurat, efisien dan tepat dalam pemecahan masalah (Hadi \& Umi Kasum, 2015). Mengingat matematika memiliki beberapa bagian yang satu dengan yang lain saling berhubungan, jadi yang paling utama dalam belajar matematika adalah bagaimana kemampuan seseorang dalam memahami konsep matematika.

Konsep mengacu pada pemahaman dasar. Siswa mengembangkan suatu konsep selagi mereka mampu mengklasifikasi atau mengelompokkan benda-benda atau ketika mereka dapat mengasosiasikan suatu nama dengan kelompok benda tertentu. (Damayanti, Mayangsari, \& Mahardhika, 2017) mendefinisikan konsep merupakan suatu yang terima dalam pikiran atau sebuah ide yang umum dan abstrak, sehingga dapat direpresentasikan sebagai penyajian internal dari sekelompok stimulus. Dapat disimpulkan bahwa pengusaan konsep sangat penting dalam mempelajari suatu mata pelajaran termasuk pada pelajaran matematika.

Pemahaman dan pengusaan konsep merupakan prasyarat untuk menguasai konsep selanjutnya. Penguasaan konsep matematika sangat dibutuhkan dalam memecahkan masalah matematika sebagai bentuk penerapan terhadap pemahaman konsep tersebut. Pemahaman konsep sangat penting karena dengan pengusaan konsep akan memudahkan siswa dalam mempelajari matematika. Indikator dari kemampuan pemahaman konsep sebagai hasil belajar matematika menurut (Juwita \& Zahra, 2019) adalah : (1) kemampuan menyatakan ulang sebuah konsep; (2) kemampuan mengklasifikasikan objek menurut sifat tertentu; (3) kemampuan memberi

Copyright $@ 2021$

Buana Matematika :

Jurnal Ilmiah Matematika dan Pendidikan Matematika 
contoh dan bukan contoh; (4) kemampuan menyajikan konsep dalam berbagai bentuk representasi matematika; (5) kemampuan mengembangkan syarat perlu dan syarat cukup dari suatu konsep; (6) kemampuan menggunakan, memanfaatkan dan memilih prosedur tertentu; (7) kemampuan mengaplikasikan konsep atau algoritma ke pemecahan masalah. Hanya 3 poin dari indikator-indikator di atas yang digunakan dalam penelitian ini karena adanya keterbatasan waktu. Indikator yang digunakan adalah : a) kemampuan menyatakan ulang sebuah konsep; b) kemampuan memberi contoh dan bukan contoh; c) kemampuan mengaplikasikan konsep atau algoritma ke pemecahan masalah.

Rendahnya pemahaman konsep matematika membuktikan bahwa salah satu faktor timbulnya kesalahan siswa dalam memecahkan suatu permasalahan matematika. Bagian yang tersulit bagi siswa yaitu memecahkan masalah, karena diperlukan keterampilan berhitung, pengusaan konsep yang tinggi, juga kemampuan dalam menggunakan bahasa yang baik, dan lain sebagainya agar siswa tidak melakukan kesalahan lagi dalam mengerjakan soal matematika. Kesalahan dalam menyelesaikan soal adalah kesalahan yang dilakukan oleh siswa karena hanya mengerjakan soal atau dua dari beberapa tahap penyelesaian soal atau tidak sesuai dengan langkah penyelesaian soal. Kesalahan siswa dalam menyelesaikan soal-soal matematika adalah kesalahan konsep, kesalahan operasi dan kesalahan ceroboh, dengan kesalahan dominan adalah kesalahan konsep. Hal tersebut dikuatkan oleh penelitian yang dilakukan Rahardjo dan Astuti (dalam Rani, 2019) bahwa kesalahan yang dialami oleh siswa dalam mengerjakan soal cerita secara mekanik meliputi kesalahan memahami soal, kesalahan membuat model matematika, dan kesalahan menginterpretasikan jawaban matematika.

Kesalahan siswa dalam menyelesaikan masalah dapat menjadi salah satu petunjuk untuk mengetahui sejauh mana siswa menguasai materi yang didapatkan sehingga perlu adanya proses analisis untuk memeriksa kemampuan siswa dalam menyelesaikan soal matematika. Salah satu cara untuk mendeskripsikan dan menganalisis kesalahan yang dilakukan siswa adalah dengan menggunakan Taksonomi SOLO (The Structure of the Observed Learning Outcome). Taksonomi SOLO dipandang dapat membantu dalam proses evaluasi hasil belajar. Dengan Taksonomi SOLO diharapkan dapat lebih baik lagi dalam melakukan evaluasi (Dwi Putri Amalia, 2019). Berdasarkan hal-hal di atas, peneliti terdorong untuk melakukan penelitian 
Jurnal Ilmiah Matematika dan Pendidikan Matematika

Vol. 11 No. 1 (2021)

dengan judul "Analisis Kesalahan Konsep Matematika Siswa Dalam Menyelesaikan Soal Sistem Persamaan Linear Dua Variabel Berdasarkan Taksonomi SOLO di Kelas VIII SMPK St. Theresia Kaca“

\section{Metode}

Penelitian ini mengunakan pendekatan kualitatif dan jenisnya adalah deskriptif. Subyek penelitian ini adalah siswa kelas VIII C SMPK St. Theresia Kaca Manggarai Barat NTT berjumlah 30 siswa, namun karena jawaban sebagian dari mereka sama, maka peneliti hanya mengambil 17 siswa dengan kategori berbeda berdasarkan tingkat Taksonomi SOLO. Instrumen dalam penelitian ini adalah tes tertulis berdasarkan Taksonomi SOLO, tes tertulis terhadap pemahaman konsep, dan lembar wawancara. Instrumen tes untuk mengetahui kemampuan menyelesaikan soal sistem persamaan linear dua variabel berdasarkan Taksonomi SOLO terdiri atas 4 butir, tes untuk mengetahui kemampuan siswa dalam menyelesaikan soal sistem persamaan linear dua variabel terhadap pemahaman konsep terdiri atas 3 butir kemudian diperkuat dengan melakukan wawancara terhadap seluruh subyek. Peneliti menggunakan triangulasi teknik untuk menguatkan kualitas keabsahan data. Analisis data penelitian ini meliputi reduksi data, penyajian data, dan penarikan simpulan (Cresswell, 2016).

\section{Hasil dan Pembahasan}

Data yang didapatkan berupa hasil tes tertulis berdasarkan Taksonomi Solo dan hasil tes tertulis terhadap pemahaman konsep siswa. Hasil yang diperoleh merupakan bentuk kesalahan yang dilakukan oleh ketujuh belas siswa pada tingkat taksonomi Solo dalam menyelesaikan soal sistem persamaan linear dua variabel terhadap pemahaman konsep. Tabel 1 menunjukkan soal sistem persamaan linear dua variabel terhadap pemahaman konsep siswa, tabel 2 menjelaskan tentang kesalahan siswa yang berada pada tingkat taksonomi Solo berdasarkan indikator pertama yaitu kemampuan menyatakan ulang sebuah konsep, tabel 3 menjelaskan tentang kesalahan siswa yang berada pada tingkat taksonomi Solo berdasarkan indikator kedua yaitu kemampuan memberikan contoh dan bukan contoh, dan tabel 4 menjelaskan tentang kesalahan siswa yang berada pada tingkat taksonomi Solo berdasarkan indikator ketiga yaitu kemampuan mengaplikasikan konsep atau algoritma kepemecahan masalah. 
Tabel 1. SoalnSistem PersamaaniLinear Dua Variabel

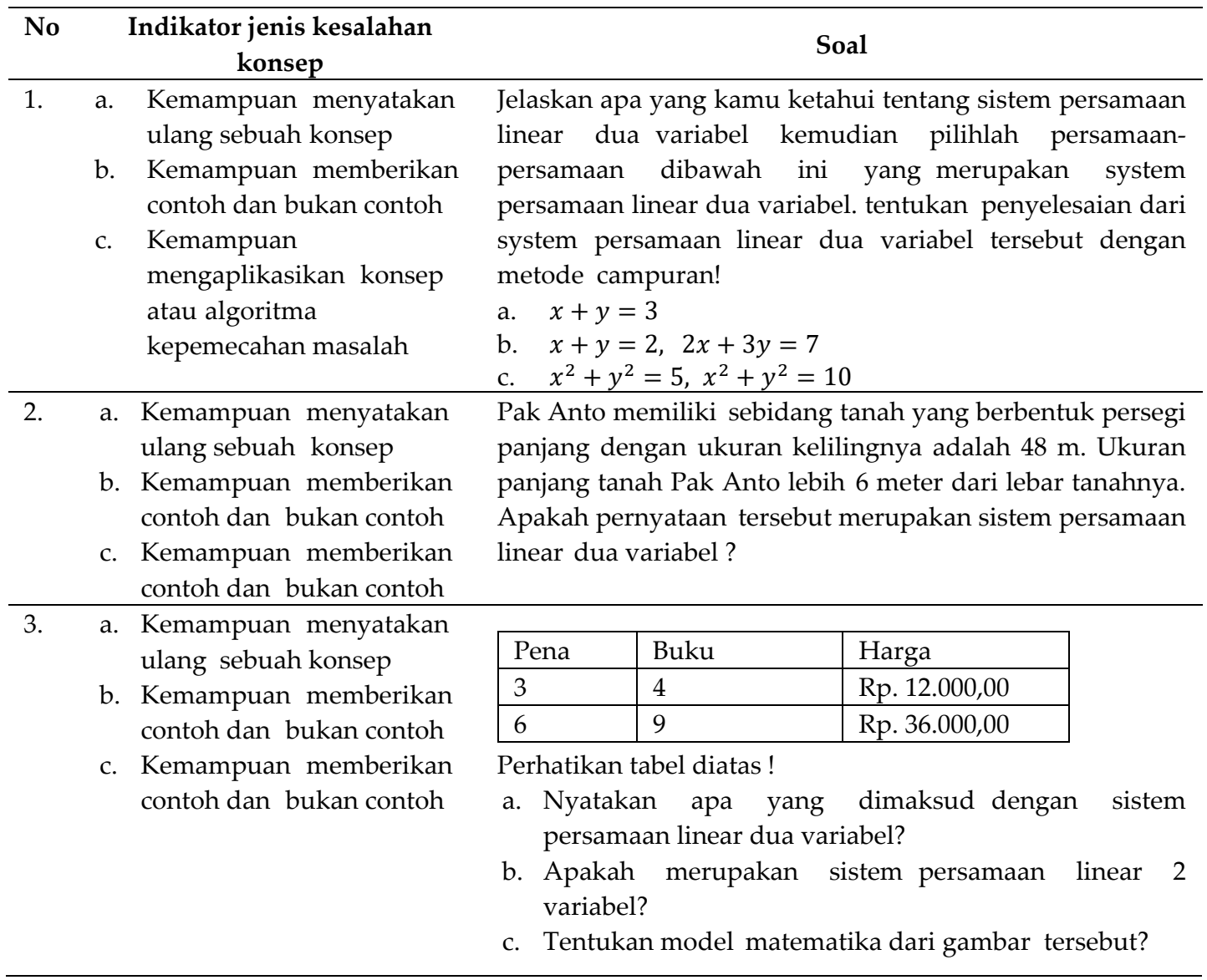

Tabel 2. Kesalahan siswa Yang Berada pada Tingkat Taksonomi Berdasarkan Indikator Pertama

\begin{tabular}{|c|c|c|c|c|c|}
\hline \multirow[b]{2}{*}{ Indikator } & \multirow{2}{*}{$\begin{array}{c}\text { Jenis } \\
\text { kesalahan }\end{array}$} & \multicolumn{4}{|c|}{ Kode Subyek } \\
\hline & & Unistruktural & Multistruktural & Relasional & $\begin{array}{l}\text { Extended } \\
\text { Abstract }\end{array}$ \\
\hline \multirow{4}{*}{$\begin{array}{c}\text { Kemampuan } \\
\text { menyatakan } \\
\text { ulang konsep }\end{array}$} & K1a & C-10,C-16 & $\begin{array}{l}\text { C- } 01, C-14, C-17, C- \\
26\end{array}$ & C-18 & $\begin{array}{l}\text { C-13,C- } \\
28\end{array}$ \\
\hline & $\mathrm{K} 1 \mathrm{~b}$ & $\begin{array}{l}\text { C-06,C-11,C- } \\
21, C-22, C- \\
24, C-25, C-29\end{array}$ & $\begin{array}{l}\text { C- } 04, C-07, C-08, C- \\
15, C-19, C-20, C-27\end{array}$ & C-30 & \\
\hline & K1c & & & & \\
\hline & K1d & $\begin{array}{l}\text { C-02,C-03,C- } \\
05, C-09\end{array}$ & $\mathrm{C}-12, \mathrm{C}-23$ & & \\
\hline
\end{tabular}

Tabel 3. Kesalahan Peserta Didik Yang Berada pada Tingkat Taksonomi Berdasarkan Indikator Kedua 
Matematika :

Jurnal Ilmiah Matematika dan Pendidikan Matematika Vol. 11 No. 1 (2021)

\begin{tabular}{|c|c|c|c|c|c|}
\hline \multirow[b]{2}{*}{ Indikator } & \multirow{2}{*}{$\begin{array}{c}\text { Jenis } \\
\text { Kesalahan }\end{array}$} & \multicolumn{4}{|c|}{ Kode Subyek } \\
\hline & & Unistruktural & Multistruktural & Relasional & $\begin{array}{l}\text { Extended } \\
\text { Abstract }\end{array}$ \\
\hline \multirow{7}{*}{$\begin{array}{l}\text { Kemampuan } \\
\text { memberikan } \\
\text { contoh dan bukan } \\
\text { contoh }\end{array}$} & $\mathrm{K} 2 \mathrm{a}$ & C-05,C-29 & C-07,C-17 & C-18,C-30 & C-28 \\
\hline & $\mathrm{K} 2 \mathrm{~b}$ & C-03,C-06,C- & C,08,C-12C- & & C-13 \\
\hline & & $09, \mathrm{C}-11, \mathrm{C}-$ & $19, C-20, C-26, C-$ & & \\
\hline & & $21, C-25$ & 27 & & \\
\hline & $\mathrm{K} 2 \mathrm{c}$ & C-22, & & & \\
\hline & $\mathrm{K} 2 \mathrm{~d}$ & C-02,C-10,C- & C-01,C-04,C- & & \\
\hline & & $16, C-24$ & $14, C-15, C-23$ & & \\
\hline
\end{tabular}

Tabel 4. Kesalahan Peserta Didik Yang Berada pada Tingkat Taksonomi Berdasarkan Indikator Ketiga

\begin{tabular}{|c|c|c|c|c|c|}
\hline \multirow[b]{2}{*}{ Indikator } & \multirow{2}{*}{$\begin{array}{c}\text { Jenis } \\
\text { Kesalahan }\end{array}$} & \multicolumn{4}{|c|}{ Kode Peserta Didik } \\
\hline & & Unistruktural & Multistruktural & Relasional & $\begin{array}{l}\text { Extended } \\
\text { Abstract }\end{array}$ \\
\hline \multirow{11}{*}{$\begin{array}{l}\text { Kemampuan } \\
\text { mengalikasikan } \\
\text { konsep atau } \\
\text { algoritma } \\
\text { kepemecahan } \\
\text { masalah }\end{array}$} & K3a & C-05,C-21C- & C-04,C-07,C- & C-30 & C-13 \\
\hline & & $22, C-25, C-29$ & $08, C-12, C-15, C-$ & & \\
\hline & & & $19, \mathrm{C}-20, \mathrm{C}-23, \mathrm{C}-$ & & \\
\hline & & & 26 & & \\
\hline & & & & & \\
\hline & & & & & \\
\hline & $\mathrm{K} 3 \mathrm{~b}$ & C-02,C-03,C- & C-01,C-27 & C-18 & C-28 \\
\hline & & $09, \mathrm{C}-11, \mathrm{C}-$ & & & \\
\hline & & $16, C-24$ & & & \\
\hline & $\mathrm{K} 3 \mathrm{c}$ & & & & \\
\hline & K3d & C-06,C-10 & C-14,C-17 & & \\
\hline
\end{tabular}

Berikut adalah hasil pekerjaan peserta didik.

Copyright $@ 2021$

Buana Matematika :

Jurnal Ilmiah Matematika dan Pendidikan Matematika 


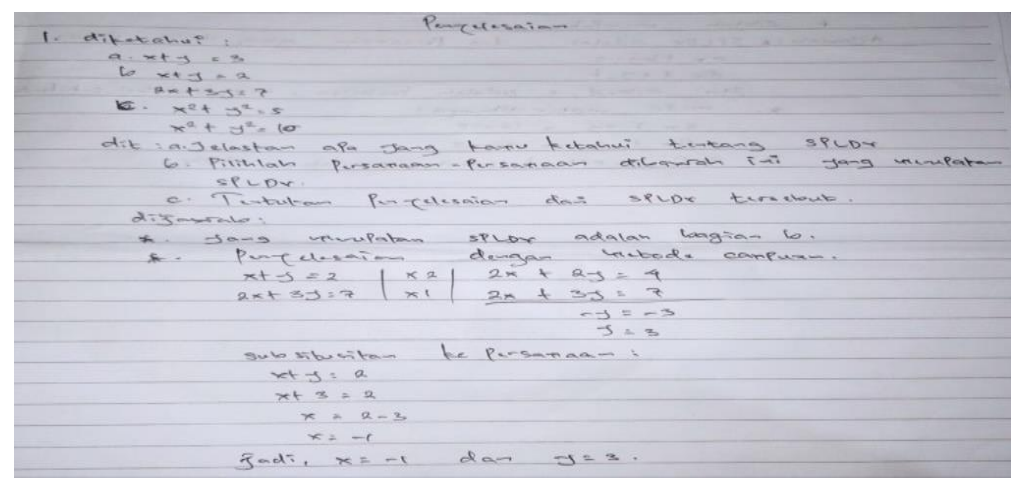

Gambar 1. HasiliPekerjaan Siswa C-11

Gambar 1 menunjukkan hasil pekerjaan peserta didik C-11 tingkat unistruktural. Subyek melakukan kesalahan pada semua indikator yaitu pada indikator pertama kemampuan menyatakan ulang sebuah konsep, kemampuan memberikan contoh dan bukan contoh, dan kemampuan mengaplikasikan konsep atau algoritma kepemecahan masalah. Subyek C11 tidak dapat mengungkapkan kembali apa itu sistem persamaan linear dua variabel, dan tidak dapat menentukan penyelesaian dari sistem persamaan linear dua variabel.

Kemudian peneliti melakukan wawancara untuk memperkuat hasil data yang diperoleh dan dapat mengetahui lebih dalam bagaimana pola pikir dari siswa dalam menyelesaikan soal sistem persamaan linear dua variabel. Dari hasil wawancara didapat bahwa subyek C-11 belum mampu mengerjakan semua soal yang diberikan karena kurang memahami materi dan mengalami kebingungan dalam mengerjakan soal.

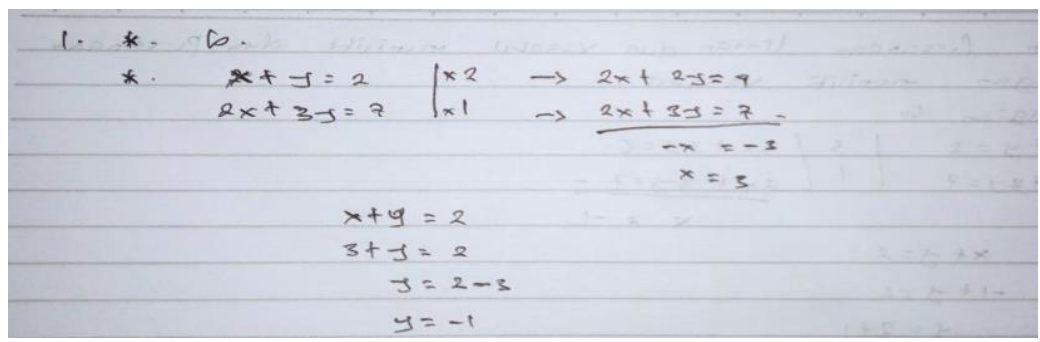

Gambar 2. Hasil Pekerjan Siswa C-27

Gambar 2 menunjukkan hasil pekerjaan siswa tingkat multistruktural. subyek melakukan kesalahan pada semua indikator pada indikator pertama kemampuan menyatakan ulang sebuah konsep, kemampuan memberikan contoh dan bukan contoh, dan kemampuan mengaplikasikan konsep atau algoritma kepemecahan masalah. Subyek tidak dapat menentukan apa yang diketahui dan yang ditanyakan dan tidak dapat menjelaskan ulang pengertian sistem persamaan linear dua variabel. 
Matematika :

Jurnal Ilmiah Matematika dan Pendidikan Matematika

Vol. 11 No. 1 (2021)

Kemudian peneliti melakukan wawancara untuk memperkuat hasil data yang diperoleh dan dapat mengetahui lebih dalam bagaimana pola pikir dari siswa dalam menyelesaikan soal sistem persamaan linear dua variabel. Dari hasil wawancara diketahui bahwa subyek C-27 masih melakukan kesalahan pada setiap nomor yang diberikan karena kurang memahami materi dan kesulitan dalam memahami soal.

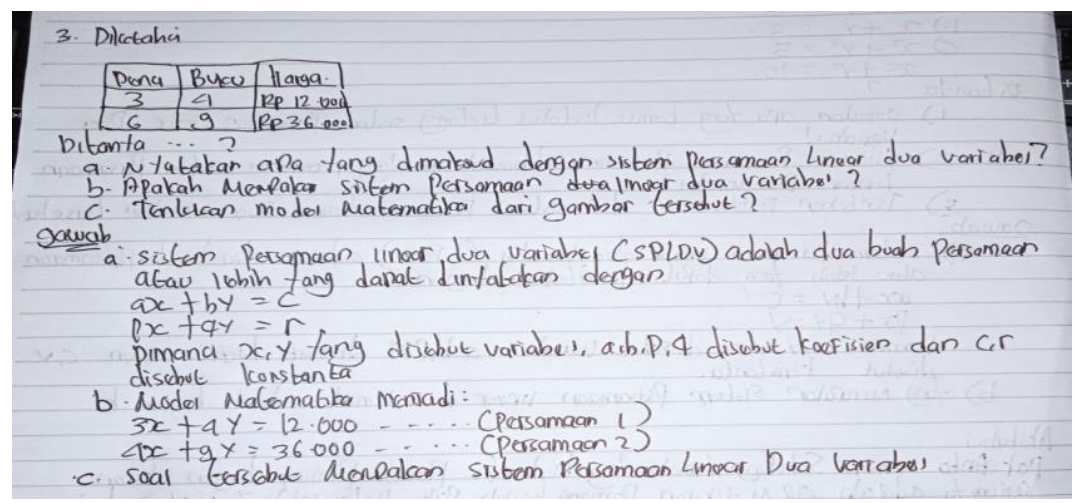

Gambar 3. Hasil Siswa Didik C-18

Gambar 3 menunjukkan hasil pekerjaan siswa tingkat relasional. subyek melakukan kesalahan pada indikator ketiga yaitu kemampuan mengaplikasikan konsep atau algoritma kepemecahan masalah. Subyek tidak mengubah soal tersebut kebentuk matematika.

Kemudian peneliti melakukan wawancara untuk memperkuat hasil data yang diperoleh dan dapat mengetahui lebih dalam bagaimana pola pikir dari siswa dalam menyelesaikan soal sistem persamaan linear dua variabel. Dari hasil wawancara diketahui bahwa subyek C-18 masih melakukan kesalahan pada nomor 3 karena kurang paham dalam mengaplikasikan soal kemodel matematika.

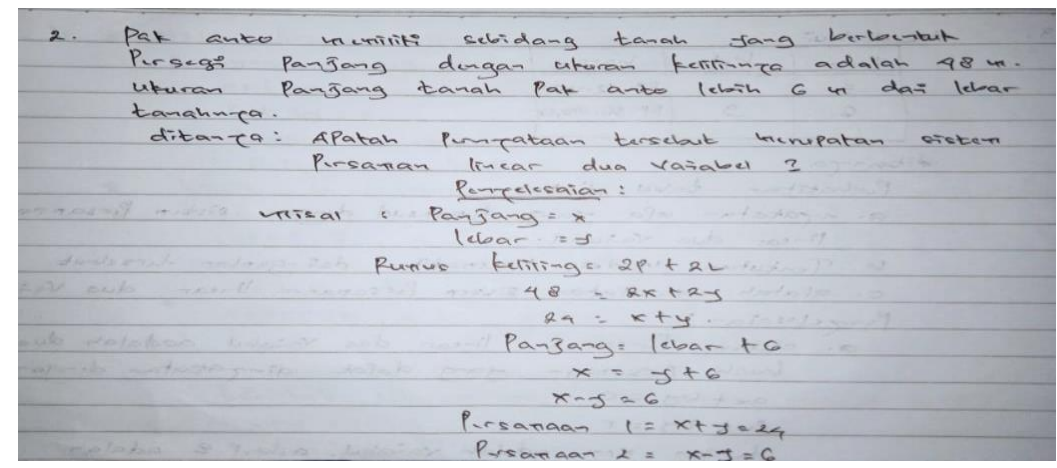

Gambar 4. Hasil Siswa Didik C-13

Pada gambar 4 menunjukan hasil pekerjaan siswa tingkat relasional. Subyek melakukan kesalahan pada pada indikator kedua yaitu kemampuan

Copyright $@ 2021$

Buana Matematika :

Jurnal Ilmiah Matematika dan Pendidikan Matematika 
memberikan contoh dan bukan contoh. Subyek tidak dapat membuat kesimpulan akhir bahwa soal tersebut merupakan sistem persamaan linear dua variabel.

Kemudian peneliti melakukan wawancara untuk memperkuat hasil data yang diperoleh dan dapat mengetahui lebih dalam bagaimana pola pikir dari siswa dalam menyelesaikan soal sistem persamaan linear dua variabel. Dari hasil wawancara diketahui bahwa subyek C-13 masih melakukan kesalahan pada nomor 3 karena lupa memberikan kesimpulan akhir yang diinginkan soal.

\section{A. Kesalahan Menyatakan Ulang Konsep}

1. Kesalahan Menyatakan Ulang Pada K1b (Kesalahan Menyatakan Ulang Konsep Tidak Lengkap) Siswa Tingkat Unistruktural.

Kesalahan menyatakan ulang konsep pada K1b siswa berdasarkan tingkat unistruktural terdapat pada semua indikator. Dari indikator tersebut siswa melakukan kesalahan diantaranya tidak dapat menjelaskan kembali sistem persamaan linear dua variabel, tidak dapat menentukan kesimpulan akhir yang diinginkan soal dan tidak dapat menentukan mana yang merupakan persamaan 1 dan mana yang merupakan persamaan 2 karena subyek tidak memahami materi sehingga tidak dapat memahami yang diinginkan dari soal. Hal ini sejalan dengan (Pujiati dan Kanzunnudin, 2018) yang mengatakan bahwa siswa mempunyai kemampuan pemahaman konsep matematika jika siswa mampu menjelaskan konsep atau mampu mengungkapkan kembali apa yang telah diberikan kepadanya, dengan menggunakan konsep pada berbagai situasi berbeda, dan mengembangkan beberapa akibat dari adanya suatu konsep.

2. Kesalahan Menyatakan Ulang Konsep Pada K1b (Kesalahan Menyatakan

Ulang Konsep Tidak Lengkap) Siswa Tingkat Multistruktural

Kesalahan menyatakan ulang konsep pada K1b siswa tingkat multistruktural terdapat pada beberapa indikator. Dari indikator tersebut siswa melakukan kesalahan diantaranya tidak dapat menentukan yang diketahui dan yang ditanyakan dan tidak dapat menentukan simpulan akhir. Hal ini sejalan dengan (Dewi et al., 2019) bahwa jenis kesalahan yang dilakukan siswa adalah kurangnya pemahaman konsep, sulit menggabungkan konsepkonsep yang dibutuhkan dalam menyelesaikan soal, dan faktor kelalaian dari siswa.

3. Kesalahan Menyatakan Ulang Konsep Pada K1b (Kesalahan Menyatakan

Ulang Konsep Tidak Lengkap) Siswa Tingkat Relasional

Kesalahan menyatakan ulang konsep pada K1b siswa tingkat relasional terdapat pada indikator kemampuan menyatakan ulang sebuah konsep. Dari

Copyright (C) 2021

Buana Matematika :

Jurnal Ilmiah Matematika dan Pendidikan Matematika 
Matematika :

Jurnal Ilmiah Matematika dan Pendidikan Matematika

Vol. 11 No. 1 (2021)

indikator tersebut siswa melakukan kesalahan karena tidak menentukan yang diketahui dan yang ditanyakan dikarenakan siswa kurang teliti dalam pengerjaan soal.

4. Kesalahan Menyatakan Ulang Konsep Pada K1d (Tidak Ada Jawaban) Siswa Tingkat Unistruktural

Kesalahan menyatakan ulang konsep pada K1d siswa tingkat unistruktural terdapat pada semua indikator. Dari indikator tersebut siswa melakukan kesalahan karena tidak menentukan yang diketahui dan yang ditanyakan, tidak dapat menjelaskan kembali pengertian dari sistem persamaan linear dua variabel, dan tidak menuliskan hasil akhir serta tidak dapat mengaplikasikan soal ke model matematika.

5. Kesalahan Menyatakan Ulang Konsep Pada K1d (Tidak Ada Jawaban) Siswa Tingkat Multistruktural

Kesalahan menyatakan ulang konsep pada K1d siswa tingkat multistruktural terdapat pada beberapa indikator. Dari indikator tersebut siswa melakukan kesalahan karena tidak menentukan yang diketahui dan yang ditanyakan, tidak dapat menjelaskan kembali pengertian dari sistem persamaan linear dua variabel, dan tidak menentukan simpulan akhir. Hal ini sejalan dengan Fathimah (2017) yang menyatakan bahwa kesalahan yang dilakukan siswa dalam menyelesaikan soal sistem persamaan linear dua variabel adalah kesalahan konsep dan kesalahan menentukan kesimpulan akhir.

\section{B. Kesalahan Memberikan Contoh dan Bukan Contoh}

1. Kesalahan Memberikan Contoh Dan Bukan Contoh Pada K1b (Kemampuan Memberikan Contoh Dan Bukan Contoh Tidak Lengkap) Siswa Tingkat Unistruktural

Kesalahan memberikan contoh dan bukan contoh pada K1b siswa tingkat unistruktural melakukan kesalahan pada semua indikator. Dari indikator tersebut siswa melakukan kesalahan karena tidak menuliskan yang diketahui dan ditanyakan, tidak dapat mengungkapkan kembali sistem persamaan linear dua variabel, tidak dapat memutuskan mana yang merupakan persamaan 1 dan persamaan 2, dan kurang mampu mengaplikasikan soal ke model matematika. Hal ini sejalan dengan (Salido, A., Misu, L., \& Salam, 2014) bahwa kesalahan konsep adalah kekeliruan dalam menggolongkan atau mengkategorikan sekumpulan objek ke dalam contoh dan bukan contoh.

2. Kesalahan Memberikan Contoh Dan Bukan Contoh Pada K2b (Kemampuan Memberikan Contoh Dan Bukan Contoh Tidak Lengkap) Siswa Tingkat Multistruktural

Copyright $@ 2021$

Buana Matematika :

Jurnal Ilmiah Matematika dan Pendidikan Matematika 
Kesalahan memberikan contoh dan bukan contoh pada K2b siswa tingkat multistruktural melakukan kesalahan pada beberapa indikator. Dari indikator tersebut siswa melakukan kesalahan karena tidak menentukan yang diketahui dan ditanyakan dan tidak membuat simpulan akhir yang diinginkan soal. Hal ini sejalan dengan (Permatasari, 2018) bahwa banyak siswa kesulitan dalam hal memahami soal matematika, lemah dalam memahami konsep sistem persamaan linear dua variabel, dan tidak dapat membedakan contoh dan bukan contoh dalam menyelesaikan soal.

3. Kesalahan memberikan contoh dan bukan contoh pada K2b (Kemampuan Memberikan Contoh Dan Bukan Contoh Tidak Lengkap) Siswa tingkat extended abstract

Kesalahan memberikan contoh dan bukan contoh pada $\mathrm{K} 2 \mathrm{~b}$ siswa tingkat extended abstract melakukan kesalahan pada indikator kemampuan memberikan contoh dan bukan contoh. Dari indikator tersebut siswa melakukan kesalahan karena lupa menuliskan kesimpulan akhir dari yang diinginkan soal.

4. Kesalahan memberikan contoh dan bukan contoh pada K2c (kemampuan memberikan contoh dan bukan contoh tidak sesuai) Siswa tingkat unsitruktural

Kesalahan memberikan contoh dan bukan contoh pada $\mathrm{K} 2 \mathrm{c}$ siswa tingkat unistruktural melakukan kesalahan pada beberapa indikator. Dari indikator tersebut siswa melakukan kesalahan karena tidak dapat menentukan yang diketahui dan ditanyakan, tidak dapat membedakan mana yang merupakan persamaan 1 dan persamaan 2 dan tidak membuat simpulan akhir dari soal.

5. Kesalahan Memberikan Contoh Dan Bukan Contoh Pada K2d (Tidak Ada Jawaban) Siswa Tingkat Unistruktural

Kesalahan memberikan contoh dan bukan contoh pada K2d siswa tingkat unistruktural melakukan kesalahan pada semua indikator. Dari indikator tersebut siswa melakukan kesalahan karena tidak dapat menentukan yang diketahui dan ditanyakan, tidak dapat menjelaskan pengertian sistem persamaan linear dua variabel, tidak dapat menentukan mana yang merupakan persamaan 1 dan mana yang merupakan persamaan 2, tidak mencantumkan hasil akhir, dan kurang mampu mengaplikasikan soal ke bentuk matematika.

6. Kesalahan Memberikan Contoh Dan Bukan Contoh Pada K2d (Tidak Ada Jawaban) Siswa Tingkat Multistruktural

Kesalahan memberikan contoh dan bukan contoh pada K2d siswa tingkat multistruktural melakukan kesalahan pada beberapa indikator. Dari indikator tersebut siswa melakukan kesalahan karena tidak dapat menentukan mana

Copyright $@ 2021$

Buana Matematika:

Jurnal Ilmiah Matematika dan Pendidikan Matematika 
Matematika :

Jurnal Ilmiah Matematika dan Pendidikan Matematika

Vol. 11 No. 1 (2021)

yang merupakan persamaan 1 dan mana yang merupakan persamaan 2, tidak membuat kesimpulan akhir yang diinginkan soal, dan kurang mampu mengaplikasikan soal kemodel matematika.

\section{Kesalahan Mengaplikasikan Konsep Atau Algoritma Kepemecahan Masalah}

1. Kesalahan mengaplikasikan konsep atau algoritma kepemecahan masalah Pada K3b (Kemampuan Mengaplikasikan Konsep atau Algoritma Tidak Lengkap) Siswa Tingkat Unistruktural

Kesalahan mengaplikasikan konsep atau algoritma kepemecahan masalah pada K3b siswa tingkat unistruktural melakukan kesalahan pada beberapa indikator. Dari indikator tersebut peserta didik melakukan kesalahan karena tidak membuat simpulan akhir dari soal, dan kurang mampu mengaplikasikan soal kemodel matematika. (Putri \& Hakim, 2019) Hal ini yang menjadi penghambat bagi siswa untuk belajar yang efisien sehingga menyebabkan siswa kesulitan mengaplikasikan soal. Ini terjadi karena peserta didik tidak mampu memahami konsep dan kurang latihan dalam pengerjaan soal sistem persamaan linear dua variabel.

2. Kesalahan Mengaplikasikan Konsep Atau Algoritma Kepemecahan Masalah K3b (Kemampuan Mengaplikasikan Konsep Atau Algoritma Tidak Lengkap) Siswa Tingkat Multistruktral

Kesalahan mengaplikasikan konsep atau algoritma kepemecahan masalah pada K3b siswa tingkat multistruktural melakukan kesalahan pada semua indikator. Dari indikator tersebut siswa melakukan kesalahan karena tidak dapat menentukan apa yang diketahui dan yang ditanyakan, tidak menuliskan kesimpulan akhir yang disuruh dan kurang mampu mengaplikasikan soal ke model matematika. Hal ini sejalan pendapat (Rahmania \& Rahmawati, 2016) Kesalahan dalam menerjemahkan soal ke dalam model matematika, kesalahan tidak dapat menjelaskan konsep variabel dan kesalahan dalam memahami konsep metode campuran dari soal tes persamaan yang diberikan. Penyebab terjadinya kesalahan yaitu siswa mengalami kesulitan dalam membaca dan memahami masalah yang terkait dengan soal yang diberikan ataupun bahasa matematis.

3. Kesalahan Mengaplikasikan Konsep Atau Algoritma Kepemecahan Masalah K3b (Kemampuan Mengaplikasikan Konsep Atau Algoritma Tidak Lengkap) Siswa Tingkat Relasional

Kesalahan mengaplikasikan konsep atau algoritma kepemecahan masalah pada K3b siswa tingkat relasional melakukan kesalahan pada indikator kemampuan mengaplikasikan konsep atau algoritma ke pemecahan

Copyright (C) 2021

Buana Matematika :

Jurnal Ilmiah Matematika dan Pendidikan Matematika 
masalah. Dari indikator tersebut peserta didik melakukan kesalahan karena ceroboh dalam mengerjakan soal.

4. Kesalahan Mengaplikasikan Konsep atau Algoritma Kepemecahan Masalah K3b (Kemampuan Mengaplikasikan Konsep atau Algoritma Tidak Lengkap) Siswa Tingkat Extended Abstract

Kesalahan mengaplikasikan konsep atau algoritma kepemecahan masalah pada K3b siswa tingkat extended abstract melakukan kesalahan pada indikator kemampuan mengaplikasikan konsep atau algoritma kepemecahan masalah. Dari indikator tersebut peserta didik melakukan kesalahan karena tidak teliti dalam mengerjakan soal.

5. Kesalahan Mengaplikasikan Konsep Atau Algoritma Kepemecahan Masalah K3d (tidak ada jawaban) Tingkat Unistruktural

Kesalahan mengaplikasikan konsep atau algoritma kepemecahan masalah pada K3d siswa tingkat unistruktural melakukan kesalahan pada beberapa indikator. Dari indikator tersebut siswa melakukan kesalahan karena tidak menentukan yang diketahui dan ditanyakan dalam soal dan tidak dapat mengubah soal cerita kebentuk matematika. Hal ini sejalan dengan (Damayanti, Mayangsari, \& Mahardhika, 2017) bahwa kesalahan dalam memahami soal dan salah dalam menentukan penyelesaiannya.

6. Kesalahan Mengaplikasikan Konsep atau Algoritma Kepemecahan Masalah K3d (tidak ada jawaban) Tingkat Multistruktural

Kesalahan mengaplikasikan konsep atau algoritma kepemecahan masalah pada K3d siswa tingkat multistruktural melakukan kesalahan pada beberapa indikator. Dari indikator tersebut siswa melakukan kesalahan karena tidak dapat membuat simpulan akhir dari soal dan kurang mampu mengaplikasikan soal ke model matematika.

\section{Simpulan}

Berdasarkan hasil penelitian dapat disimpulkan bahwa pada indikator kemampuan menyatakan ulang konsep siswa melakukan kesalahan diantaranya menyatakan ulang konsep tidak lengkap (K1b) dilakukan oleh siswa tingkat unistruktural, multistruktural, dan relasional, serta kesalahan lain adalah tidak menjawab soal yang diberikan dilakukan oleh siswa tingkat unistruktural dan multistruktural. Pada indikator kemampuan memberikan contoh dan bukan contoh siswa melakukan kesalahan antara lain memberikan contoh dan bukan contoh tidak lengkap (K2b) dilakukan oleh siswa tingkat unistruktural, multistrukutral, dan extended absrtract. Kesalahan selanjutnya yaitu memberikan contoh dan bukan contoh tidak sesuai (K2c) dilakukan oleh siswa tingkat unistruktural serta kesalahan karena tidak ada jawaban (K2d) dilakukan oleh siswa tingkat unistruktural

Copyright (C) 2021

Buana Matematika :

Jurnal Ilmiah Matematika dan Pendidikan Matematika 
Matematika :

Jurnal Ilmiah Matematika dan Pendidikan Matematika Vol. 11 No. 1 (2021)

dan multistruktural. Pada indikator kemampuan mengaplikasikan konsep atau algoritma kepemecahan masalah siswa melakukan kesalahan yaitu mengaplikasikan konsep atau algoritma kepemecahan masalah tidak lengkap (K3b) dilakukan siswa tingkat unistruktural, multistruktural, relasional dan extended abstract serta kesalahan lain adalah tidak menjawab (K3d) dilakukan oleh siswa tingkat unistruktural dan multistruktural.

Melihat hasil penelitiaan di atas, peneliti menyarankan kepada guru untuk menekankan pemahaman konsep kepada siswa dan memberi bimbingan lebih dalam mengerjakan soal secara runtut sesuai dengan indikator agar tidak terjadi kesalahan konsep matematika. Bagi peneliti lain yang akan meneliti masalah serupa, hendaknya lebih mengembangkan butir-butir tes dan melakukan wawancara yang lebih mendalam untuk mendapatkan hasil penelitian yang lebih tajam dan akurat.

\section{Daftar Pustaka}

Andriani, T., Suastika, I. K., \& Sesanti, N. R. (2017). Analisis Kesalahan Konsep Matematika Siswa dalam Menyelesaikan Soal Trigonometri Kelas X TKJ SMKN 1 Gempol Tahun Pelajaran 2016/2017. Mathematics Education Journal, 1(1), 34-39. https://doi.org/10.21067/pmej.v1i1.1998

Creswell, J. W. (2016). Research Design Pendekatan Metode Kualitatif, Kuantitatif, Dan Campuran. Yogyakarta: PT Remaja Rosdakarya.

Damayanti, N. W., Mayangsari, S. N., \& Mahardhika, L. T. (2017). Analisis

Kesalahan Siswa Dalam Pemahaman Konsep Operasi Hitung Pada Pecahan. Jurnal Ilmiah Edutic/Vol, 4(1).

Dedeng, E., Fayeldi, T., \& Ferdiani, R. D. (2020). Analisis Miskonsepsi Siswa Kelas VII Pada Sub Materi Penyelesaian Spldv Dan Penerapan Spldv Menggunakan Three Tier-Test. Jurnal Terapan Sains \& Teknologi, 2(2), 129-135.

Dewi, R., Lambertus, \& Hafilidin. (2019). Analisis Kesalahan Dalam Menyelesaiakan Soal Persamaan Garis Lurus Pada Siswa Kelas VIII MTs Negeri 2 Kendari. Pendidikan Matematika, 7(3), 57-71.

Dwi Putri Amalia, Y. (2019). Analisis Kesalahan Peserta Didik Kelas VII SMPN 22 Padang DDalam Menyelesaikan Soal-Soal Matematika Berdasarkan Taksonomi SOLO. 8(2), 11-17.

Gesela Marisa, Syaiful, B. H. (2020). Analisis Kesalahan Siswa Dalam Menyelesaikan Soal Operasi Aljabar Berdasarkan Taksonomi SOLO. Jurnal Pendidikan Matematika, 11(1), 77-88.

Copyright $@ 2021$

Buana Matematika :

Jurnal Ilmiah Matematika dan Pendidikan Matematika 
Hadi, S., \& Umi Kasum, M. (2015). Pemahaman Konsep Matematika Siswa SMP Melalui Penerapan Model Pembelajaran Kooperatif Tipe Memeriksa Berpasangan (Pair Checks). Pendidikan Matematika, 3(1), 59-66. https://doi.org/10.20527/edumat.v3i1.630

Juwita, S., \& Zahra, A. (2019). Analisis kesalahan siswa dalam pemahaman konsep menyelesaikan soal cerita spldv dengan tahapan newman. Jurnal Pembelajaran Matematika Inovatif, 2(2), 87-94.

Maulana, F., \& Pujiastuti, H. (2020). Analisis Kesalahan Siswa SMADalam Menjawab Soal Dimensi Tiga Berdasarkan Teori Newman. MAJU: Jurnal Ilmiah Pendidikan Matematika, 7(2), 182-190.

Nur Rofi'ah, Ansori, H., \& Mawaddah, S. (2019). Analisis kesalahan siswa dalam menyelesaikan soal cerita matematika berdasarkan langkah penyelesaian polya. Jurnal Pendidikan Matmatika, 7(2), 120-129. https://doi.org/10.20527/edumat.v7i2.7379

Pujiati , Mohammad Kanzunnudin, S. W. (2018). Analisis Pemahaman Konsep Matematis Siswa Kelas Iv Sdn 3 Gemulung Pada Materi Pecahan. Anargya: Jurnal Ilmiah Pendidikan Matematika, 1(1), 37-41. https://doi.org/10.24176/anargya.v1i1.2278

Rahmania, L., \& Rahmawati, A. (2016). Analisis Kesalahan Siswa dalam Menyelesaikan Soal Cerita Persamaan Linier Satu Variabel. 1(2), 165-174. https://doi.org/10.26594/jmpm.v1i2.639

Salido, A., Misu, L., \& Salam, M. (2014). Analisis Kesalahan Siswa Dalam Menyelesaikan Soal-Soal Matematika Materi Pokok Limit Fungsi Pada Siswa Kelas XI IPA 2 SMA Negeri 5 Kendari A. Jurnal Penelitian Pendidikan Matematika, 2(1), 1-13.

Setiyaningsih, Wiwik. "Analisis Kesalahan Siswa Kelas X IPA.2 SMA Negeri 1 Ujungbatu Dalam Menyelesaikan Soal Pada Materi Pertidaksamaan Rasional Dan Irasional." Jurnal Pendidikan Matematika 1.1:34-38 
Matematika :

Jurnal Ilmiah Matematika dan Pendidikan Matematika Vol. 11 No. 1 (2021)

Copyright (C) 2021

Buana Matematika :

Jurnal Ilmiah Matematika dan Pendidikan Matematika 